\title{
Foliar application of defoliants after winter chill accumulation changes phytohormone dynamics and improves budbreak in blackberry under subtropical climatic conditions
}

\author{
Syuan-You Lin ${ }^{1} \cdot$ Shinsuke Agehara ${ }^{1}$ (D)
}

Received: 1 January 2021 / Accepted: 28 February 2021 / Published online: 15 March 2021

(c) The Author(s) 2021

\begin{abstract}
Inadequate winter chill causes poor budbreak in blackberry (Rubus L. subgenus Rubus Watson), limiting the commercial production in the subtropics. In 'Natchez' blackberry, our previous study found that, under inadequate chilling conditions, urea and lime sulfur (LS) applied as defoliants before chill accumulation advanced budbreak but did not improve final budbreak. In this study, we applied the two defoliants at the end of chill accumulation and examined their effectiveness in breaking dormancy, with a hypothesis that it can be enhanced with increased exposure to chilling. Field experiments were conducted over two growing seasons under subtropical climatic conditions. 'Natchez' blackberry was sprayed with urea or LS at $10 \%$. Both defoliants were effective in both advancing and maximizing budbreak. Final budbreak reached $42.6 \%$ to $76.8 \%$ in the defoliant treatments, compared with $27.1 \%$ to $31.6 \%$ in the control. Advanced budbreak by defoliants increased early season yield by $35 \%$ to $88 \%$. Although not statistically significant, defoliants increased total-season yield by $19 \%$ to $56 \%$, compared with the control. Phytohormone profiling revealed no changes in abscisic acid and gibberellic acid 4, but increasing trends in jasmonic acid and indole-3-acetic acid (IAA) during budbreak. The LS treatment increased IAA accumulation by up to $377 \%$ compared with the control. These results suggest that urea and LS are highly effective dormancy-breaking agents for blackberry when applied after winter chill accumulation. These defoliants could be an important adaptation tool for subtropical blackberry production. Furthermore, increased IAA accumulation appears to be, at least in part, the mode of action for LS-induced budbreak.
\end{abstract}

Keywords Chilling requirement $\cdot$ Defoliation $\cdot$ Dormancy $\cdot$ Plant growth regulator $\cdot$ Plant hormone $\cdot$ Rubus

\section{Introduction}

Blackberry (Rubus L. subgenus Rubus Watson) is a deciduous perennial berry crop originating from temperate regions in America, Europe, and East Asia. Blackberry buds enter dormancy during winter to survive unfavorable climatic conditions (Warmund et al. 1992). Dormant plants experience arrested growth and reduced metabolic activities (Arora et al. 2003). Buds do not break dormancy until they are exposed to a certain amount of winter chill, referred to as the

Communicated by Zhong-Hua Chen.

Shinsuke Agehara

sagehara@ufl.edu

1 Gulf Coast Research and Education Center, Institute of Food and Agricultural Sciences, University of Florida, 14625 CR 672, Wimauma, FL, 33598, USA chilling requirement. Current floricane-fruiting blackberry cultivars require $300-900 \mathrm{~h}$ of winter chill (below $7.2^{\circ} \mathrm{C}$ ) (Drake and Clark 2000; Carter et al. 2006). Consequently, commercial blackberry production concentrates primarily in temperate regions with adequate winter chill, such as Serbia, Hungary, Northwestern United States, highlands in Mexico, and northern and central coastal areas in China (Strik et al. 2007).

The global blackberry industry has experienced rapid growth in recent years, driven by increased consumption, improved cultivars, and advanced cultural practices (Clark and Finn 2014). In the United States, blackberry retail sales increased from $\$ 549$ million in 2016 to $\$ 697$ million in 2019 (California Strawberry Commission 2019). Local food movements and high demand from growers for alternative crops contributed to the recent expansion of blackberry cultivation into non-traditional production areas (Gangwer 2013). In the southeastern United States, production acreage 
increased by 52\% (996 vs. 1512 ha) from 2007 to 2017 [U.S. Department of Agriculture (USDA) 2017]. In subtropical regions of southern Brazil, a $111 \%$ increase in production acreage ( 250 vs. 528 ha) was recorded from 2005 to 2012 (Strik et al. 2007; Antunes et al. 2014). Globally, however, subtropical blackberry production is still limited because of inadequate winter chill, which leads to incomplete dormancy release, poor budbreak, erratic flowering, and ultimately low fruit yield (Fear and Meyer 1993; Lin and Agehara 2020a).

Artificial budbreak induction using dormancy breaking agents is one of the strategies to produce temperate crops under inadequate chilling conditions. In Mexico, it is reported that some fertilizers are used as defoliants in combination with gibberellic acid $\left(\mathrm{GA}_{3}\right)$ and thidiazuron to promote budbreak of 'Brazo' and 'Tupi' blackberry (Strik et al. 2007). In Florida, United States, we previously conducted a series of experiments to evaluate several budbreak induction methods for subtropical blackberry production. Our previous study demonstrated that $\mathrm{GA}_{3}$ is a highly effective bud dormancy-breaking agent for blackberry (Lin and Agehara 2020a). However, we also discovered that $\mathrm{GA}_{3}$ causes cultivar-dependent flower abortion, which is a drawback to its commercial implementation (Lin and Agehara 2020b). In the most recent study, we found that urea and lime sulfur (LS) applied at the beginning of chill accumulation advanced budbreak by up to 66 days but had no significant effect on the final budbreak percentage (Lin and Agehara 2021). In general, the effectiveness of dormancy-breaking agents is affected by the application timing. To maximize budbreak induction, dormancy-breaking agents are often applied after the exposure to adequate winter chill (Díaz et al. 1987; Erez 1995; Sheard et al. 2009) or at the onset of dormancy release (Faust et al. 1997).

Bud dormancy is regulated by the complex crosstalk of phytohormones, including abscisic acid (ABA), gibberellins (GA), and indole-3-acetic acid (IAA) (Liu and Sherif 2019; Fadón et al. 2020). In deciduous fruit crops, ABA levels increase at the onset of bud dormancy and decline during chill accumulation, whereas GA and IAA show the opposite trend (Ionescu et al. 2017b; Ito et al. 2019; Yamane et al. 2019). Some studies suggest that jasmonic acid (JA) also plays a role in dormancy regulation. For example, Juvany et al. (2015) reported that JA accumulation occurred during the transition from dormancy to budbreak in beech (Fagus sylvatica L.). Hao et al. (2017) found that, in tea (Camellia sinensis L. O. Kuntze), the expression of JA synthesis genes was down-regulated during dormancy but up-regulated during budbreak. In some temperate fruit crops, these phytohormone dynamics during natural budbreak can be induced by hydrogen cyanamide (HC) (Zheng et al. 2015; Wang et al. 2017; Ionescu et al. 2017a; Liang et al. 2019). In blackberry, however, no study has quantified phytohormones in buds or investigated their responses to dormancy-breaking agents.
In this study, we hypothesized that the effectiveness of urea and LS in breaking bud dormancy can be enhanced with increased exposure to winter chill before treatment. The objective of this study was to examine the effects of the two defoliants applied at the end of chill accumulation on defoliation, budbreak, yield, and fruit quality of 'Natchez' blackberry grown under subtropical climatic conditions. We also performed phytohormone profiling to understand potential roles of phytohormones in budbreak of blackberry.

\section{Materials and methods}

\section{Experiment site and plant material}

Two field experiments were conducted at a commercial blackberry farm located in Plant City, Florida, United States (lat. $28^{\circ} 03^{\prime} \mathrm{N}$, long. $82^{\circ} 19^{\prime} \mathrm{W}$, elevation $39 \mathrm{~m}$ ) during the 2018-2019 and 2019-2020 seasons. An erect floricanefruiting cultivar, 'Natchez', was used. Because a gradual decline of plant vigor was observed in 'Natchez' (Bolda 2012), different areas of the farm were used to ensure the uniformity of plant vigor between the two growing seasons. The estimated chilling requirement of this cultivar is about $300 \mathrm{~h}$ (McWhirt 2017a). The cultural practices used in this commercial blackberry farm were described in our previous study (Lin and Agehara 2021). For each growing season, cumulative chilling hours (below $7.2^{\circ} \mathrm{C}$ ) between 1 Nov. and 30 Mar. were obtained from the Florida Automated Weather Network (http://agroclimate.org/tools/Chill-Hours-Calcu lator/).

\section{Defoliant treatment and experiment design}

In both seasons, treatments included the water control and two defoliants: urea and LS. The equippments used for defoliant application were described in our previous study (Lin and Agehara 2021). The spray volume was $1870 \mathrm{~L} \mathrm{ha}^{-1}$. In the 2018-2019 season, urea and LS were sprayed at $187 \mathrm{~kg} \mathrm{ha}^{-1}(10 \%$, w/w) on $19 \mathrm{Feb} .2019$. In the 2019-2020 season, the same defoliant treatments were performed on 19 Feb. 2020. A nonionic surfactant (Agri-Dex ${ }^{\circledR}$, Helena Chemical Co., Collierville, Tennessee, USA) was added at $0.5 \%(\mathrm{v} / \mathrm{v})$ to all defoliant treatments including the water control.

In the 2018-2019 season, an incomplete unbalanced randomized block design with four blocks was used. In the 2019-2020 season, all treatments had five replicated plots arranged in a complete randomized design. In both growing seasons, each plot consisted of three to five plants. 


\section{Defoliation and budbreak}

Five representative floricanes were selected per plot to determine temporal changes in defoliation and budbreak. Cane selection and data collection were performed using the method described by Lin and Agehara (2021).

\section{Marketable yield and fruit quality}

In the 2018-2019 season, fully ripen berries were harvested 10 times between 2 May and 14 June 2019: six times in May and four times in June. In the 2019-2020 season, fully ripen berries were harvested 10 times between 7 May and 11 June 2020: seven times in May and three times in June. May and June yields were considered early, and late-season yields, respectively. We graded harvested berries according to the USDA grade standards (USDA 2016). Both U.S. No. 1 and U.S. No. 2 berries were considered marketable.

In the 2019-2020 season, the four largest (by weight) marketable berries were sampled per plot during three peak harvests. Fruit quality was assessed using the method described by Lin and Agehara (2021).

\section{Phytohormone profiling}

Buds were sampled from the control and LS treatment at 4 days before treatment (DBT) and 3 and 6 days after treatment (DAT). Buds sampled at 4 DBT were pooled, and only the composite sample was used for phytohormone analysis. Buds sampled at 3 and 6 DAT were stored and analyzed individually for each treatment. Collected samples were frozen in liquid nitrogen and stored at $-80^{\circ} \mathrm{C}$. The frozen tissues were ground in liquid nitrogen to fine powder using the mortar and pestle, and quickly weighed $(\approx 100 \mathrm{mg}$ ) into a pre-chilled $1.5 \mathrm{~mL}$ eppendorf tube. Phytohormone extraction and quantification were performed following the methods described by Almeida Trapp et al. (2014). In brief, cold methanol:water $(70: 30, v / v)$ was immediately added to the samples. The samples were vortexed and sonicated, then extracted at $4{ }^{\circ} \mathrm{C}$ for $30 \mathrm{~min}$, and centrifuged at $16,000 \times g$ at $4{ }^{\circ} \mathrm{C}$ for $5 \mathrm{~min}$. The supernatant was transferred into a new eppendorf tube and dried under nitrogen stream. Each sample was redissolved in $100 \%$ methanol plus labeled standards and the supernatant injected into a Waters Acquity I class UPLC connected to a Waters Xevo TQ-XS mass spectrometer (Waters Co., Milford, USA). Separation was carried out using a BEH C18 column $1.76 \mu \mathrm{m}, 2.1 \times 150 \mathrm{~mm}$ (Waters Co., Milford, USA) with $\mathrm{H}_{2} \mathrm{O} / 0.05 \%$ formic acid (solvent A) and acetonitrile $/ 0.05 \%$ formic acid (solvent B) starting with 5\% solvent B for $1 \mathrm{~min}$, a gradient from 5 to $95 \%$ of solvent B over $4 \mathrm{~min}$, hold at $95 \%$ solvent $\mathrm{B}$ for $0.5 \mathrm{~min}$, then back to
$5 \%$ solvent $\mathrm{B}$ in $3 \mathrm{~min}$ at a flow rate of $0.45 \mathrm{~mL} \mathrm{~min}^{-1}$. The temperature of the UPLC column was set to $40{ }^{\circ} \mathrm{C}$. The source temperature was $150{ }^{\circ} \mathrm{C}$; desolvation gas temperature: $550{ }^{\circ} \mathrm{C}$; desolvation gas flow: $1000 \mathrm{~mL} \mathrm{~min}^{-1}$, cone gas flow: $150 \mathrm{~mL} \mathrm{~min}^{-1}$; nebulizer: 7 psi. Cone and collision energy were optimized for each hormone individually; IAA, $\mathrm{d}_{5} \mathrm{IAA}, \mathrm{MeJA}$ and $\mathrm{d}_{5} \mathrm{MeJA}$ were analyzed in the positive ion mode while negative mode was used for $\mathrm{JA}, \mathrm{d}_{5} \mathrm{JA}$, ABA, $\mathrm{d}_{6} \mathrm{ABA}, \mathrm{GA}_{4},{ }^{2} \mathrm{H}_{2} \mathrm{GA}_{4}$, and $\mathrm{GA}_{3}$. The selected reaction monitoring (SRM) analysis conditions were optimized for each phytohormone and internal standard. TargetLynx XS software (version 4.2; Waters Co., Milford, USA) was used to quantify peak area and the amount of constitutive hormone was based on comparison to labeled hormones.

\section{Statistical analysis}

All data were analyzed by the generalized linear mixed model procedure (PROC GLIMMIX) in the SAS statistical software (SAS 9.4; SAS Institute Inc., Cary, NC, USA). Because experiment design was different between the two seasons, statistical analysis was performed within each season. In the 2018-2019 season, treatments were considered as a fixed factor, whereas blocks were considered as a random factor. In the 2019-2020 season, treatments were considered as a fixed factor, and no random effects were considered.

Marketable yield and phytohormone data were modeled with the lognormal distribution (DIST = LOGNORMAL), berry size (e.g. berry fresh weight, length, and width) data were modeled with the normal distribution (DIST $=$ NORMAL), fruit SSC data were modeled with the beta distribution $($ DIST $=$ BETA). For model parameter estimation and degrees of freedom adjustment, the procedures described by Lin and Agehara (2021) were followed.

Defoliation and budbreak data were collected in a repeated measures design and thus subjected to repeated measure analysis. Fixed factors were treatments, time, and treatment $\times$ time in both seasons. Random factors were blocks and block $\times$ treatment in the 2018-2019 season and replication $\times$ treatment in the 2019-2020 season. The appropriate covariance structure was identified following the procedures described by Lin and Agehara (2021).

For marketable yield and phytohormone data, means and standard errors were back-transformed to the original scale using the Delta method. For defoliation and budbreak data, data were rescaled to the original scale by using the inverse link option (ILINK) in the LSMEANS statement. Least square means comparisons were performed using the Tukey-Kramer test. Unless otherwise noted, $P$ values less than 0.05 were considered statistically significant. Backtransformed or rescaled data are reported in this study. 


\section{Results}

\section{Defoliation}

In the 2018-2019 season, moderate defoliation occurred prior to defoliant treatments, with the percentage of defoliation ranging from 71.2 to $73.7 \%$ at 1 DBT (Fig. 1a). In the control, defoliation progressed slowly from $74.9 \%$ at 9 DAT to $85.4 \%$ at 31 DAT. Urea induced nearly complete defoliation at 9 DAT, resulting in significantly greater defoliation than the control from 9 to 31 DAT (74.9-85.4\% vs. $99.2-99.9 \%)$. Defoliation induced by LS was also severe but somewhat slower compared to urea. The LS treatment had significantly greater defoliation than the control from 24 to 31 DAT (83.7-85.4\% vs. 97.9-98.7\%).

In the 2019-2020 season, defoliation at 7 DBT was similar among the treatments, ranging from 45.9 to $49.8 \%$ at 7 DBT (Fig. 1a). In the control, defoliation progressed slowly but steadily, reaching $68.0 \%$ at 34 DAT. Out of the two defoliants, only urea accelerated defoliation. From 6 to 34 DAT, defoliation remained significantly greater in the urea treatment (91.7\% to $98.2 \%$ ) than in the control (55.6\% to $68.0 \%)$. In the LS treatment, although defoliation gradually increased up to $80.1 \%$ at 34 DAT, no significant difference was detected compared with the control.

A

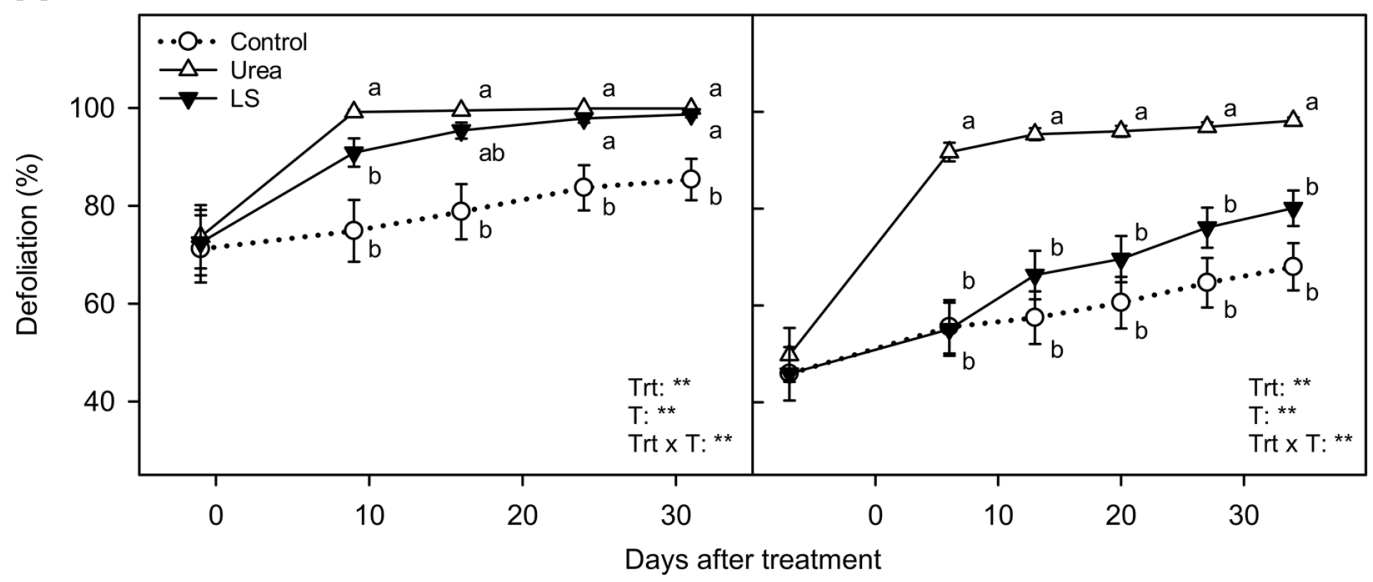

B
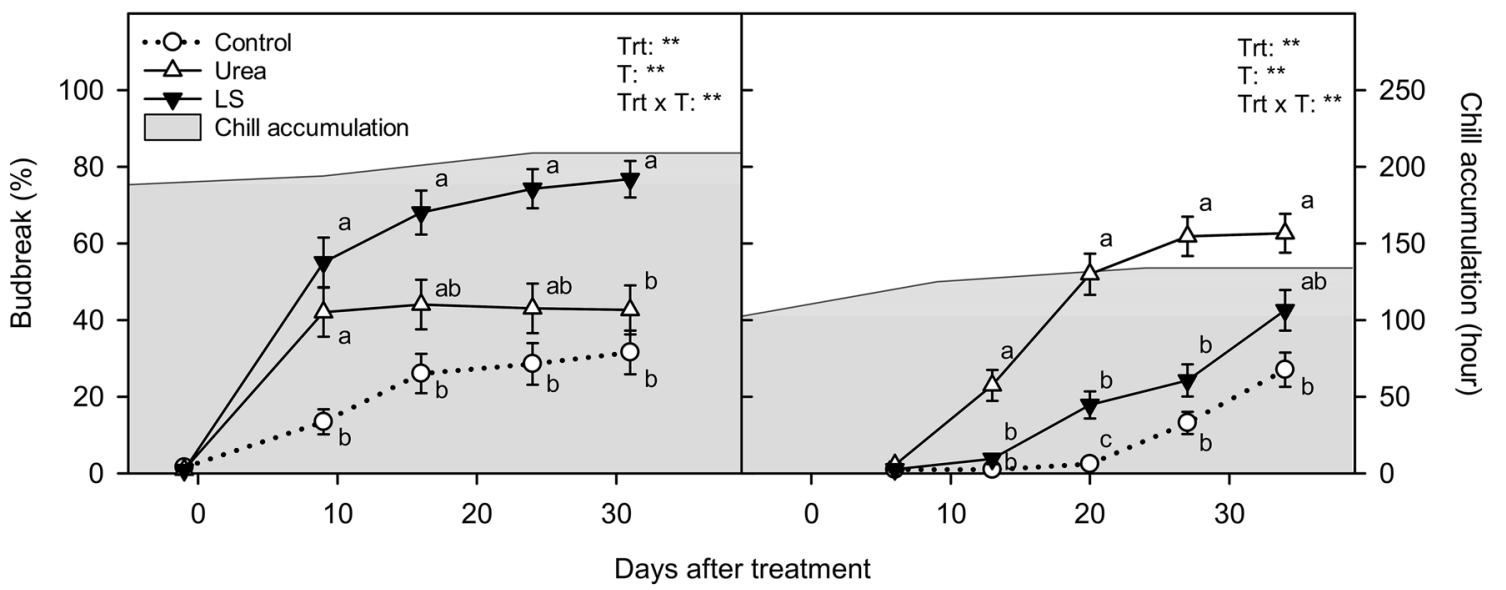

Fig. 1 Defoliation and budbreak of 'Natchez' blackberry grown under subtropical conditions as affected by defoliants. a Defoliation in the 2018-2019 season and the 2019-2020 season. b Budbreak in the 2018-2019 season and the 2019-2020 season. Plants were treated with defoliants at $187 \mathrm{~kg} \mathrm{ha}^{-1}$ via spray application $\left(1870 \mathrm{~L} \mathrm{ha}^{-1}\right)$ on 19 Feb. 2018 in the 2018-2019 season, and on 19 Feb. 2019 in the 2019-2020 season. A non-ionic surfactant (Agri-Dex®) was added at $0.5 \%(\mathrm{v} / \mathrm{v})$ to all treatments including the control. Trt, $\mathrm{T}$ and
$\operatorname{Trt} \times \mathrm{T}$ indicate the effect of the defoliant treatment, time, and interaction between the defoliant treatment and time, respectively. NS, *, ** indicate treatment effects that are not significant or significant at $P<0.05$, or 0.01 , respectively. Means ( $\mathrm{n}=4$ in the 2018-2019 season; $\mathrm{n}=5$ in 2019-2020 season) with the same or no letter within each measurement day are not significantly different (Tukey-Kramer test, $P<0.05)$. $L S$ lime sulfur 


\section{Budbreak}

In the 2018-2019 season, budbreak was limited among the treatment at $1 \mathrm{DBT}$, ranging from 0.9 to $1.6 \%$ (Fig. 1b). In the control, budbreak initiated and started increasing from $13.5 \%$ at 9 DAT to $31.6 \%$ at 31 DAT. Both urea (42.1\%) and LS $(55.1 \%)$ induced significantly greater budbreak than the control $(13.5 \%)$ at 9 DAT. From 16 to 24 DAT, similar trends were observed: the LS (68.1-74.3\%) and urea treatments (43.1-44.1\%) showed greater budbreak than the control (26.1-28.6\%), but only budbreak induced by LS was significantly different compared with the control. At 31 DAT, LS induced greater budbreak (76.8\%). However, no significant difference was detected between the urea treatment $(42.7 \%)$ and control $(31.6 \%)$.

In the 2019-2020 season, we did not observe any budbreak when the treatments were performed on 19 Feb. 2019 (data not shown). In the control, budbreak was negligible (1.0-2.5\%) until 20 DAT but increased gradually thereafter, reaching $13.2 \%$ at 27 DAT and $27.1 \%$ at 34 DAT (Fig. 1b). Compared with the control, the onset of budbreak was advanced by urea and LS by 14 and 7 days, respectively. From 13 to 27 DAT, urea (23.0-61.9\%) induced greater budbreak than the control (1.0-13.2\%) and LS (3.8-24.3\%). In the LS treatment, although it transiently showed greater budbreak than the control at 20 DAT (2.5 vs. $17.9 \%$ ), this difference became non-significant thereafter. At 34 DAT, urea induced the greatest budbreak $(62.7 \%)$, followed by LS (42.6\%) and control (27.1\%). The final budbreak showed a significant difference only between the control and urea treatment.

\section{Marketable yield}

In the 2018-2019 season, peak harvests occurred in May, accounting for 73 to $83 \%$ of total-season yield (Table 1). Although no significant difference was detected, increasing trends were observed with the defoliant treatments: compared with the control, the urea and LS treatments increased early season yield by $35 \%$ and $55 \%$, respectively, and totalseason yield by $19 \%$ and $56 \%$, respectively.

In the 2019-2020 season, yield distribution was similar to the 2018-2019 season, with $70 \%$ to $87 \%$ of yield occurring in May. Compared with the control, the urea and LS treatments increased early season yield by $88 \%$ and $46 \%$, respectively, but the difference was significant only for the urea treatment. Although not statistically significant, totalseason yield was increased by the urea and LS treatments by $51 \%$ and $17 \%$, respectively, compared with the control.

\section{Berry size and quality}

Significant treatment effects were detected in both berry size (fresh weight, length, and width) and SSC (Table 2). The control produced $14 \%$ heavier berries than the urea and LS treatments (8.4 vs. $7.4 \mathrm{~g} /$ berry). A similar trend was observed in berry length and width, with the control producing 3 to $4 \%$ longer and 4 to $5 \%$ wider berries than the urea and LS treatments. There was no significant difference between the urea and LS treatments in any berry size measurement. Fruit SSC was increased by the urea and LS treatments by $2 \%$ and $5 \%$, respectively, compared with the control.

Table 1 Marketable yield of 'Natchez' blackberry grown under subtropical conditions as affected by defoliants in the 2018-2019 and 20192020 seasons

\begin{tabular}{|c|c|c|c|c|c|c|}
\hline \multirow[t]{3}{*}{ Treatment $^{\mathrm{a}}$} & \multicolumn{6}{|c|}{ Marketable yield $\left(\mathrm{t} \mathrm{ha}^{-1}\right)$} \\
\hline & \multicolumn{3}{|c|}{ 2018-2019 season $^{\mathrm{c}}$} & \multicolumn{3}{|c|}{ 2019-2020 season ${ }^{\mathrm{d}}$} \\
\hline & Early & Late & Total & Early & Late & Total \\
\hline Control & $6.27 \pm 1.82^{\mathrm{b}}$ & $1.95 \pm 0.66$ & $8.54 \pm 2.09$ & $2.80 \pm 0.45 b^{f}$ & $1.18 \pm 0.29$ & $4.02 \pm 0.58$ \\
\hline Urea & $8.47 \pm 2.45$ & $1.60 \pm 0.54$ & $10.20 \pm 2.50$ & $5.26 \pm 0.84 \mathrm{a}$ & $0.63 \pm 0.15$ & $6.07 \pm 0.88$ \\
\hline LS & $9.71 \pm 2.81$ & $2.88 \pm 0.97$ & $13.36 \pm 3.27$ & $4.09 \pm 0.65 \mathrm{ab}$ & $0.62 \pm 0.15$ & $4.72 \pm 0.69$ \\
\hline$P$ value ${ }^{\mathrm{e}}$ & 0.560 & 0.432 & 0.476 & 0.048 & 0.146 & 0.171 \\
\hline
\end{tabular}

$L S$ lime sulfur

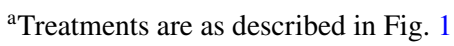

${ }^{\mathrm{b}}$ Data are means $\pm \mathrm{SE}$

${ }^{c}$ Early and late-season yields represented six harvests in May and four harvests in June, respectively

${ }^{\mathrm{d}}$ Early and late-yields represented seven harvests in May and three harvests in June, respectively

${ }^{\mathrm{e}} P$ values indicate the significance of the treatment effect

${ }^{\mathrm{f}}$ Means ( $\mathrm{n}=4$ in the 2018-2019 season; $\mathrm{n}=5$ in 2019-2020 season) in a column followed by the same letter or no letter are not significantly different (Tukey-Kramer test, $P<0.05$ ) 
Table 2 Berry size and soluble solids concentration (SSC) of 'Natchez' blackberry grown under subtropical conditions as affected by defoliants in the 2019-2020 season ${ }^{\mathrm{b}}$

\begin{tabular}{lllll}
\hline Treatment $^{\mathrm{a}}$ & Berry FW $(\mathrm{g})$ & Berry length $(\mathrm{cm})$ & Berry width $(\mathrm{cm})$ & Fruit SSC $\left({ }^{\circ}\right.$ Brix $)$ \\
\hline Control & $8.44 \mathrm{a}^{\mathrm{d}}$ & $2.60 \mathrm{a}$ & $2.41 \mathrm{a}$ & $9.74 \mathrm{c}$ \\
Urea & $7.42 \mathrm{~b}$ & $2.44 \mathrm{~b}$ & $2.29 \mathrm{~b}$ & $9.92 \mathrm{~b}$ \\
LS & $7.42 \mathrm{~b}$ & $2.41 \mathrm{~b}$ & $2.27 \mathrm{~b}$ & $10.21 \mathrm{a}$ \\
$P$ value $^{\mathrm{c}}$ & 0.005 & 0.031 & 0.012 & 0.000 \\
\hline
\end{tabular}

$L S$ lime sulphur, $F W$ fresh weight

${ }^{\text {a }}$ Treatments are as described in Fig. 1

${ }^{\mathrm{b}}$ Data were collected from three peak harvests between 18 May and 2 June 2019

${ }^{\mathrm{c}} P$ values indicate the significance of the treatment effect

${ }^{\mathrm{d}}$ Means $(\mathrm{n}=5)$ in a column followed by the same letter or no letter are not significantly different (Tukey-Kramer test, $P<0.05$ )

\section{Phytohormones}

Buds in the control remained dormant from 3 to 6 DAT. Compared with the control, LS-treated buds started swelling at 3 DAT and showed visible budbreak at 6 DAT (Fig. 2a). Both $\mathrm{ABA}$ and $\mathrm{GA}_{4}$ production remained similar in the control and LS treatment at 3 and 6 DAT (Fig. 2b, c). Although JA production was decreased by the LS treatment by $36 \%$ at 3 DAT, this difference was only marginally significant $(P=0.058)$ (Fig. 2d). At 6 DAT, JA production did not differ between the control and LS treatment. Significant treatment effects were detected only in IAA production (Fig. 2e). IAA production was increased by the LS treatment by $377 \%$ and $293 \%$ at 3 and 6 DAT, respectively, compared with the control. The abundance of $\mathrm{GA}_{3}$ was below our level of detection (data not shown).

\section{Discussion}

\section{Potential roles of defoliation in budbreak induction}

Under warm winter temperatures, defoliation and budbreak are often delayed and poor in temperate fruit crops (Walser et al. 1981). One of the important functions of defoliation is to allow floral buds to become receptive to winter chilling, which in turn helps fulfill chilling requirements and reduce the depth of dormancy (Lloyd and Firth 1990; Olmstead 2015). Consequently, defoliants can be used as a strategy to maximize winter chill accumulation by inducing early defoliation. However, it is unlikely that the application method of urea and LS used in this study served this strategy. First, cumulative chilling hours were only 209 and $134 \mathrm{~h}$ in the first and second growing seasons (Fig. 1b), respectively, which were not adequate to satisfy the chilling requirement of 'Natchez' blackberry (300 h) (McWhirt 2017a). Second, defoliants were applied at the end of chill accumulation: 75 to $93 \%$ of chilling hours were recorded before the application of defoliants. Nonetheless, both urea and LS successfully promoted budbreak of 'Natchez' blackberry, demonstrating that their budbreak induction effects are not mediated by increases in winter chill accumulation. Therefore, it is likely that budbreak induction by urea and LS involves other mechanisms, such as elevated oxidative stress (Maleva et al. 2015) and increased tissue nitrogen concentration (Singh et al. 2002; Thitithanakul et al. 2012).

Interestingly, no clear relationship was found between defoliation and budbreak in this study. In the first growing season, urea induced defoliation more rapidly than LS, but LS induced a higher percentage of budbreak than urea. This observation suggests that defoliation itself does not trigger budbreak. It also supports our theory discussed above that defoliant-induced budbreak may involve elevated oxidative stress (Maleva et al. 2015) or increased tissue nitrogen concentration (Singh et al. 2002; Thitithanakul et al. 2012).

\section{Winter chill may differently affect defoliation and budbreak induction effects of urea and LS}

Defoliation and budbreak induction effects of LS varied considerably between the two growing seasons, whereas those of urea remained relatively consistent. First, complete defoliation was achieved by both urea and LS in the first growing season but only by urea in the second growing season. Second, budbreak was promoted by LS to a greater extent than by urea in the first growing season, but the opposite trend occurred in the second growing season. Although overcropping often results in a gradual decline of plant vigor in 'Natchez' (Bolda 2012), this was not the case in this study because different areas of the farm were used in the two growing seasons. Therefore, the reduced effectiveness of LS in the second growing season was due likely to environmental factors. 
Fig. 2 Phytohormone levels of 'Natchez' blackberry grown under subtropical conditions as affected by the LS treatment in the 20182019 season. a Flower bud development at 3 and 6 days after treatment (DAT). b Abscisic acid (ABA). c Gibberellic acid $4\left(\mathrm{GA}_{4}\right)$. d Jasmonic acid (JA). e Indole-3-acetic acid (IAA). Treatments are as described in Fig. 1. Means $(n=4)$ with the same or no letter within each measurement day are not significantly different (Tukey-Kramer test, $P<0.05)$ ). $L S$ lime sulfur, $F W$ fresh weight

Winter chill accumulation can affect the effectiveness of some defoliants or dormancy-breaking agents (Erez 1995; Sheard et al. 2009). It is reported that insufficient chilling weakens the responsiveness of blueberry and table grape to hydrogen cyanamide in a subtropical climate (Dokoozlian et al. 1995; Mohamed et al. 2010; Williamson 2014). In apple, Díaz et al. (1987) reported that the final percentage of budbreak increased from 25 to $80 \%$ by delaying urea application from mid-December to early January under low winter chill conditions. In this study, plants received 193 and 101 chilling hours before defoliant treatments in the first and second growing seasons, respectively. Chilling triggers the floral transition in temperate crops (Henderson and Dean 2004). Therefore, the fact that the effectiveness of LS was reduced in a warmer winter suggests that the floral transition stage plays an important role in the mode of action of LS. In other words, to activate the effect of LS, floral buds may need to be advanced to a specific development stage. Our results also suggest that urea and LS have different modes of action in the regulation of defoliation and budbreak, and that the mode of action of urea is independent of chill accumulation or the floral development stage.

\section{Urea and LS affect yield and yield distribution}

Advanced budbreak by defoliants resulted in $35 \%$ to $88 \%$ increases in early season yield. By contrast, June yield showed reductions by up to $47 \%$ in response to defoliants, except for the LS treatment in the first growing season. These contrasting seasonal yield responses to defoliants reflect changes in yield distribution caused by more concentrated early bud break and fruit set. In central Florida, blackberry harvesting typically occurs between early May and late June (Lin and Agehara 2020a). The average rainy season runs from late May through October (Supplemental Fig. 1), thereby overlapping with the late-season blackberry harvest and increasing the risk of disease damage or physiological disorders, such as sunscald and red duplet reversion (McWhirt 2017b; Lin and Agehara 2018; Edgley et al. 2019). Therefore, our results suggest that defoliants have the potential to improve not only early season yield but also fruit quality and marketability by avoiding unfavorable weather conditions.

Under subtropical climatic conditions, budbreak and yield of blackberry are limited because of the lack of chill
$0.5 \mathrm{~cm} A$
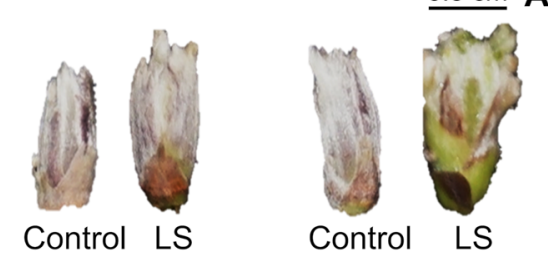

3 DAT

6 DAT

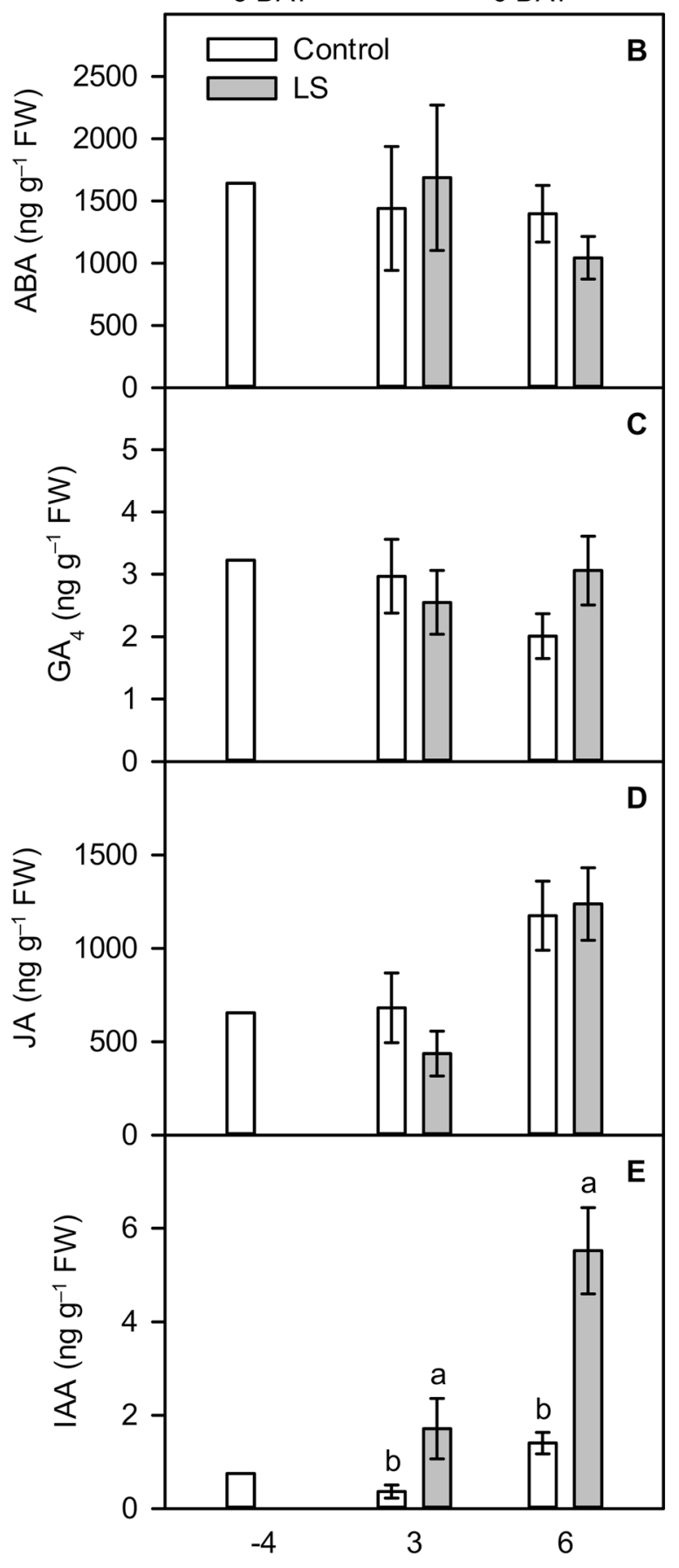

Days af ter treatment 
accumulation (Lin and Agehara 2020a). The average commercial blackberry yield in the United States from 2007 to 2017 was $10.3 \mathrm{t} \mathrm{ha}^{-1}$, according to the USDA's National Agricultural Statistics Service (USDA 2020). In this study, total-season yield ranged from 4.02 to $8.54 \mathrm{t} \mathrm{h}^{-1}$ in the control, 6.07 to $10.20 \mathrm{t} \mathrm{ha}^{-1}$ in the urea treatment, and 4.72 to $13.36 \mathrm{t} \mathrm{ha}^{-1}$ in the LS treatment, accounting for up to $61 \%$, $99 \%$, and $130 \%$ of the average commercial yield, respectively. These results suggest that, using defoliants as dormancy-breaking agents, blackberry yield at the commercial level is feasible even in subtropical climates.

\section{Changes in phytohormone production during budbreak induction by LS}

Phytohormone synthesis and catabolism change dramatically during dormancy and budbreak, regulating these important phenological events in response to changes in environmental conditions. In this study, because budbreak occurred in the LS treatment during the bud sampling period, our data provide insight into the hormonal regulation of budbreak in blackberry and the mode of action of LS. To the best of our knowledge, this is the first study reporting changes in phytohormone production during budbreak in blackberry.

The transition between dormancy and budbreak is regulated by the complex crosstalk of phytohormones (Liu and Sherif 2019). The antagonistic roles of ABA and GA are particularly well documented. In many Rosaceae fruit crops, ABA levels increase at the onset of bud dormancy and decline during chill accumulation, whereas the exact opposite trend occurs with GA. In this study, however, both $\mathrm{ABA}$ and $\mathrm{GA}_{4}$ levels were relatively consistent. Because buds were sampled at the end of chill accumulation, it is likely that the modulation of $\mathrm{ABA}$ and $\mathrm{GA}_{4}$ levels occurred before the measurement period.

In addition to GA, JA accumulation plays an important role in budbreak of some perennial crops. Juvany et al. (2015) reported that JA levels steadily increased from dormancy to budbreak in beech in northeastern Spain (lat. $\left.42^{\prime} \mathrm{N}\right)$. A transcriptome study also found that the expressions of JA synthesis genes were down-regulated during dormancy but up-regulated during budbreak in tea plants in East-Central China (lat. 30'N) (Hao et al. 2017). In this study, there were increasing trends in JA levels during budbreak, suggesting that JA accumulation may also be involved in budbreak of blackberry. Interestingly, although LS significantly promoted budbreak, JA levels were not different between the control and LS treatment. In HC-treated sweet cherry, Ionescu et al. (2017a) reported that the conversion of JA to jasmonoyl-isoleucine occurred during budbreak. Therefore, this JA conversion may explain the lack of significant treatment effects on JA in this study.
As a growth-promoting phytohormone, IAA levels generally remain low during dormancy but increase rapidly during budbreak (Ionescu et al. 2017b; Zhang et al. 2018; Ito et al. 2019; Yamane et al. 2019). Our results were in agreement with the previous findings, suggesting that IAA is also involved in budbreak of blackberry. Most notably, the stimulation of IAA production by LS coincided with the timing of budbreak, further indicating its important role in budbreak induction. Many sulfur-containing substances are effective in breaking bud dormancy in table grape (Vitis vinifera L.) (Kubota et al. 1999; Vargas-Arispuro et al. 2008). LS can release hydrogen sulfide after being dissolved in water, which is a highly toxic gas known for its characteristic rotten egg smell (USDA 2014). Zhang et al. (2009) reported that hydrogen sulfide increased IAA levels in shoot tips of sweet potato (Ipomoea batatas $\mathrm{L}$ ). Therefore, hydrogen sulfide released from LS could be the active ingredient for stimulating IAA production, and thus budbreak in blackberry.

The budbreak and phytohormone results suggest that poor budbreak in blackberry under inadequate chilling conditions is due partly to insufficient IAA production. Furthermore, increased IAA accumulation appears to be, at least in part, the mode of action for LS-induced budbreak. Dormancy is regulated not only by phytohormone production but also signal reception and transduction (Horvath et al. 2003). For, example, recent studies found that GA and ABA signal reception and transduction are involved in dormancy release in sweet cherry (Prunus avium L.) and Asian pear (Pyrus pyrifolia white pear group) (Li et al. 2018; Vimont et al. 2020). Quantifying the expression of genes related to phytohormone signaling may help elucidate the regulatory role of phytohormones in budbreak of blackberry.

\section{Practical implications}

Our results demonstrate that urea and LS are effective dormancy-breaking agents for blackberry, and that they can be an important management tool for subtropical blackberry production. Importantly, these defoliants have several key features for successful commercial implementation. First, urea and LS are relatively safe compared with HC. Although hydrogen cyanamide is widely used as a dormancy-breaking agent for some temperate crops (Ionescu et al. 2017b), its major drawbacks are hazardous chemical properties and potential environmental pollution (Eckel 2007; Schep et al. 2009). Second, both urea and LS are readily available: urea is a common nitrogen fertilizer, and LS is a fungicide labeled for controlling fungal diseases in blackberry. Third, they have no negative side effects on fruit development and quality.

Cost effectiveness is also an important consideration to develop chemical budbreak induction as a commercial management strategy. Based on the prices at a local 
major supplier of agricultural chemicals and the application method used in this study, the application costs of urea and LS are \$165 and \$580 per hectare, respectively, of which $\$ 35$ is for the adjuvant (Agri-Dex®). Therefore, urea appears to be the ideal chemical option not only because of its consistent efficacy and favorable safety profile, but also because of its low application cost.

Chilling requirements vary considerably among blackberry cultivars (Drake and Clark 2000; Carter et al. 2006). In this study, only one low-chill floricane-fruiting cultivar, 'Natchez', was used. In general, 'Natchez' requires 300 chilling hours, whereas other major floricane-fruiting cultivars require 400 to 900 chilling hours. In contrast to floricanefruiting cultivars, primocane-fruiting cultivars have little chilling requirements, but their budbreak is observed to be still limited in Florida (Agehara et al. 2020). Therefore, the effectiveness of defoliants in inducing budbreak should be tested for high-chill floricane-fruiting and primocane-fruiting cultivars. Additional studies are also needed to optimize the application rate and spray volume of each defoliant for maximizing budbreak induction.

Under current global warming scenarios, dramatic winter chill reductions are projected to occur worldwide (Almazroui et al. 2020; Ilori and Ajayi 2020; Luedeling 2012). In California, United States, for example, winter chill is projected to decrease by 50 to $75 \%$ by the mid-twenty-first century (Luedeling et al. 2009). Therefore, chemical induction of budbreak by urea could become an important management tool to cope with future loss of winter chill in temperate blackberry production.

Supplementary Information The online version contains supplementary material available at https://doi.org/10.1007/s10725-021-00703-x.

Acknowledgements We thank Dustin Grooms for allowing us to conduct experiments in his orchard and for his cooperation, Dr. Dante Pinochet for his assistance during data collection and insightful comments, and all members of Horticultural Crop Physiology Lab at the Gulf Coast Research and Education Center for their technical assistance.

Funding This study was supported in part by the Florida Specialty Crop Block Grant Program (USDA-AMS-SCBGP-2019).

\section{Declarations}

Conflict of interest The authors declare no conflict of interest. The use of brand names and any mention or listing of commercial products or services in the publication does not imply endorsement by University of Florida nor discrimination against similar products or services not mentioned.

Open Access This article is licensed under a Creative Commons Attribution 4.0 International License, which permits use, sharing, adaptation, distribution and reproduction in any medium or format, as long as you give appropriate credit to the original author(s) and the source, provide a link to the Creative Commons licence, and indicate if changes were made. The images or other third party material in this article are included in the article's Creative Commons licence, unless indicated otherwise in a credit line to the material. If material is not included in the article's Creative Commons licence and your intended use is not permitted by statutory regulation or exceeds the permitted use, you will need to obtain permission directly from the copyright holder. To view a copy of this licence, visit http://creativecommons.org/licenses/by/4.0/.

\section{References}

Agehara S, Lin SY (2020) Deng Z (2020) choosing the right blackberry cultivar in subtropical Florida. EDIS 1:6. https://doi.org/10.32473/ edis-hs1352-2019

Almazroui M, Saeed S, Saeed F et al (2020) Projections of precipitation and temperature over the South Asian countries in CMIP6. Earth Syst Environ 4:297-320. https://doi.org/10.1007/ s41748-020-00157-7

Almeida Trapp M, DeSouza GD, Rodrigues-Filho E et al (2014) Validated method for phytohormone quantification in plants. Front Plant Sci 5:1-11. https://doi.org/10.3389/fpls.2014.00417

Antunes LEC, dos Pereira IS, Picolotto L et al (2014) Produção de amoreira-preta no Brasil. Rev Bras Frutic 36:100-111. https:// doi.org/10.1590/0100-2945-450/13

Arora R, Rowland LJ, Tanino K (2003) Induction and release of bud dormancy in woody perennials: a science comes of age. HortScience 38(5):911-921. https://doi.org/10.21273/HORTSCI.38.5.911

Bolda M (2012) Pruning of 'Natchez' blackberry. https://ucanr.edu/ blogs/blogcore/postdetail.cfm?postnum=7642. Accessed $25 \mathrm{Apr}$ 2017

California Strawberry Commission (2019) Retail category trends report. https://www.calstrawberry.com/en-us/market-data/retailcategory-trends. Accessed 21 Sept 2020

Carter PM, Clark JR, Particka CD, Crowne DY (2006) Chilling response of Arkansas blackberry cultivars. J Am Pomol Soc 60:187-197

Clark JR, Finn CE (2014) Blackberry cultivation in the world. Rev Bras Frutic 36:46-57. https://doi.org/10.1590/0100-2945-445/13

Díaz DH, Alvarez A, Sandoval J (1987) Cultural and chemical practices to induce uniform bud break of peach and apple under warm climates in Mexico. Acta Hortic 199:129-136. https://doi.org/10. 17660/actahortic.1987.199.31

Dokoozlian NK, Williams LE, Neja RA (1995) Chilling exposure and hydrogen cyanamide interact in breaking dormancy of grape buds. HortScience 30(6):1244-1247. https://doi.org/10.21273/HORTS CI.30.6.1244

Drake CA, Clark JR (2000) Determination of the chilling requirement of Arkansas thornless blackberry cultivars. Stud J Dale Bump Coll Agric Food Life Sci 1:30-32

Eckel WP (2007) Ecological risk assessment problem formulation for: cyanamide. United States Environmental Protection Agency, Washington, DC

Edgley M, Close DC, Measham PF (2019) Effects of climatic conditions during harvest and handling on the postharvest expression of red drupelet reversion in blackberries. Sci Hortic 253:399-404. https://doi.org/10.1016/j.scienta.2019.04.052

Erez A (1995) Means to compensate for insufficient chilling to improve bloom and leafing. Acta Hortic 395:81-96. https://doi.org/10. 17660/ActaHortic.1995.395.7

Fadón E, Fernandez E, Behn H, Luedeling E (2020) A conceptual framework for winter dormancy in deciduous trees. Agronomy 10:241. https://doi.org/10.3390/agronomy 10020241

Faust M, Erez A, Rowland L et al (1997) Bud dormancy in perennial fruit trees: physiological basis for dormancy induction. HortScience 32:623-629 
Fear CD, Meyer MDL (1993) Breeding and variation in Rubus germplasm for low winter chill requirement. Acta Hortic 352:295-304. https://doi.org/10.17660/ActaHortic.1993.352.42

Gangwer K (2013) The state of local food in the Central Ohio River Valley. Green Umbrella. https://www.uc.edu/cdc/5_19_14_State ofLocalFoodReport.pdf. Accessed 31 Dec 2020

Hao X, Yang Y, Yue C et al (2017) Comprehensive transcriptome analyses reveal differential gene expression profiles of Camellia sinensis axillary buds at para-, endo-, ecodormancy, and bud flush stages. Front Plant Sci 8:1-19. https://doi.org/10.3389/fpls. 2017.00553

Henderson IR, Dean C (2004) Control of Arabidopsis flowering: the chill before the bloom. Development 131:3829-3838. https://doi. org/10.1242/dev.01294

Horvath DP, Anderson JV, Chao WS, Foley ME (2003) Knowing when to grow: signals regulating bud dormancy. Trends Plant Sci 8:534-540

Ilori OW, Ajayi VO (2020) Change detection and trend analysis of future temperature and rainfall over West Africa. Earth Syst Environ 4:493-512. https://doi.org/10.1007/s41748-020-00174-6

Ionescu IA, López-Ortega G, Burow M et al (2017a) Transcriptome and metabolite changes during hydrogen cyanamide-induced floral bud break in sweet cherry. Front Plant Sci 8:1233. https://doi.org/ 10.3389/fpls.2017.01233

Ionescu IA, Møller BL, Sánchez-Pérez R (2017b) Chemical control of flowering time. J Exp Bot 68:369-382. https://doi.org/10.1093/ jxb/erw427

Ito A, Tuan PA, Saito T et al (2019) Changes in phytohormone content and associated gene expression throughout the stages of pear (Pyrus pyrifolia Nakai) dormancy. Tree Physiol. https://doi.org/ 10.1093/treephys/tpz101

Juvany M, Müller M, Munné-Bosch S (2015) Bud vigor, budburst lipid peroxidation, and hormonal changes during bud development in healthy and moribund beech (Fagus sylvatica L.) trees. Trees 29:1781-1790. https://doi.org/10.1007/s00468-015-1259-3

Kubota N, Yamane Y, Toriu K et al (1999) Identification of active substances in garlic responsible for breaking bud dormancy in grapevines. J Jpn Soc Hortic Sci 68:1111-1117

Li J, Xu Y, Niu Q, He L, Teng Y, Bai S (2018) Abscisic acid (ABA) promotes the induction and maintenance of pear (Pyrus pyrifolia white pear group) flower bud endodormancy. Int J Mol Sci 19:310. https://doi.org/10.3390/ijms19010310

Liang D, Huang X, Shen Y et al (2019) Hydrogen cyanamide induces grape bud endodormancy release through carbohydrate metabolism and plant hormone signaling. BMC Genomics 20:1-14. https://doi.org/10.1186/s12864-019-6368-8

Lin SY, Agehara S (2018) Phenology, yield and fruit quality of floricane-fruiting blackberry cultivars under high tunnel and net house production systems in Florida. Proc Fla State Hortic Soc 131:13-16

Lin SY, Agehara S (2020a) Exogenous gibberellic acid advances reproductive phenology and increases early-season yield in subtropical blackberry production. Agronomy 10:1317. https://doi.org/10. 3390/agronomy 10091317

Lin SY, Agehara S (2020b) Exogenous gibberellic acid and cytokinin effects on budbreak, flowering, and yield of blackberry grown under subtropical climatic conditions. HortScience 55(12):19381945. https://doi.org/10.21273/HORTSCI15381-20

Lin SY, Agehara S (2021) Foliar application of defoliants before winter chill accumulation advances budbreak and improves fruit earliness of blackberry under subtropical climatic conditions. HortScience 56(2):210-216. https://doi.org/10.21273/HORTSCI15533-20

Liu J, Sherif SM (2019) Hormonal orchestration of bud dormancy cycle in deciduous woody perennials. Front Plant Sci 10:1136. https://doi.org/10.3389/fpls.2019.01136
Lloyd J, Firth D (1990) Effect of defoliation time on depth of dormancy and bloom time for low-chill peaches. HortScience 25:1575-1578

Luedeling E (2012) Climate change impacts on winter chill for temperate fruit and nut production: a review. Sci Hortic 144:218-229. https://doi.org/10.1016/j.scienta.2012.07.011

Luedeling E, Zhang M, Girvetz EH (2009) Climatic changes lead to declining winter chill for fruit and nut trees in California during 1950-2099. PLoS ONE 4:e6166. https://doi.org/10.1371/journal. pone. 0006166

Maleva M, Borisova G, Chukina N, Prasad MNV (2015) Urea-induced oxidative damage in Elodea densa leaves. Environ Sci Pollut Res 22:13556-13563. https://doi.org/10.1007/s11356-015-4600-x

McWhirt A (2017a) Blackberry variety selection. https://www.uaex. edu/farm-ranch/crops-commercial-horticulture/horticulture/ commercial-fruit-production/blackberry-school.aspx. Accessed 20 Nov 2020

McWhirt A (2017b) What is going on with my blackberry fruit? Identifying blackberry fruit disorders. https://www.uaex.edu/ farm-ranch/crops-commercial-horticulture/horticulture/arfruit-veg-nut-update-blog/posts/fruitdisorders.aspx. Accessed 21 May 2018

Mohamed HB, Vadel A, Khemira H (2010) Estimation of chilling requirement and effect of hydrogen cyanamide on budbreak and fruit characteristics of 'Superior Seedless' table grape cultivated in a mild winter climate. Pak J Bot 42:1761-1770

Olmstead M (2015) Defoliating peaches. Citrus Industry. https:// crec.ifas.ufl.edu/extension/trade_journals/2015/2015_Septe mber_peaches.pdf. Accessed 17 Sept 2019

Schep L, Temple W, Beasley M (2009) The adverse effects of hydrogen cyanamide on human health: an evaluation of inquiries to the New Zealand National Poisons Centre. Clin Toxicol 47:58 60. https://doi.org/10.1080/15563650802459254

Sheard AG, Johnson SD, Cook NC (2009) Effect of timing and concentration of rest breaking agents on budburst in 'Bing' sweet cherry under conditions of inadequate winter chilling in South Africa. S Afr J Plant Soil 26:73-79. https://doi.org/10.1080/ 02571862.2009.10639937

Singh G, Singh AK, Rajan S, Bhriguvanshi SR (2002) Strategy for crop regulation in guava (Psidium guajava $\mathrm{L}$ ) through foliar urea sprays and its effect on different $\mathrm{N}$-forms in leaves. J Appl Hortic 04(02):93-98. https://doi.org/10.37855/jah.2002.v04i02. 26

Strik BC, Clark JR, Finn CE, Ban MP (2007) Comprehensive crop reports worldwide blackberry production. HortTechnology 17:205-213

Thitithanakul S, Ṕtel G, Chalot M, Beaujard F (2012) Supplying nitrate before bud break induces pronounced changes in nitrogen nutrition and growth of young poplars. Funct Plant Biol 39:795-803. https://doi.org/10.1071/FP12129

U.S. Department of Agriculture (2014) Lime Sulfur - Agricultural Marketing Service - USDA. U.S. Department of Agriculture. https://www.ams.usda.gov/sites/default/files/media/LimeSulfur EvaluationTR.pdf. Accessed 4 Apr 2019

U.S. Department of Agriculture (2016) United States standards for grades of dewberries and blackberries. U.S. Department of Agriculture. https://www.ams.usda.gov/sites/default/files/ media/DewberriesBlackberriesStandard.pdf. Accessed $25 \mathrm{Apr}$ 2019

U.S. Department of Agriculture (2017) USDA/ NASS Quickstats Ad-Hoc Query Tool. U.S. Department of Agriculture. https:// quickstats.nass.usda.gov/results/08D195DC-7B67-32E7-91674314A69E6E69. Accessed 8 July 2019

U.S. Department of Agriculture (2020) Commercial acreage, yield per acre, production, and grower price. U.S. Department of Agriculture. https://www.ers.usda.gov/webdocs/DataFiles/ 
54499/FruitYearbookBerries_Dsss.xlsx?v=7577. Accessed 31 Dec 2020

Vargas-Arispuro I, Corrales-Maldonado C, Martínez-Téllez MÁ (2008) Compounds derived from garlic as bud induction agents in organic farming of table grape. Chil J Agric Res 68:94-101. https://doi. org/10.4067/s0718-58392008000100009

Vimont N, Schwarzenberg A, Domijan M, Donkpegan ASL, Beauvieux R, le Dantec L et al (2020) Fine tuning of hormonal signaling is linked to dormancy status in sweet cherry flower buds. Tree Physiol. https://doi.org/10.1093/treephys/tpaa122

Walser RH, Walker DR, Seeley SD (1981) Effect of temperature, fall defoliation and gibberellic acid on the rest period of peach buds. J Am Soc Hortic Sci 106:91-94

Wang L, Zhang C, Huang J et al (2017) Hydrogen cyanamide improves endodormancy release and blooming associated with endogenous hormones in 'Summit' sweet cherry trees. N Z J Crop Hortic Sci 45:14-28. https://doi.org/10.1080/01140671.2016.1229344

Warmund MR, Takeda F, Davis GA (1992) Supercooling and extracellular ice formation in differentiating -buds of eastern thornless blackberry. J Am Soc Hortic Sci 117(6):941-945. https://doi.org/ 10.21273/JASHS.117.6.941

Williamson JG (2014) Review of Hydrogen Cyanamide Practices in Florida Blueberries. https://www.floridablueberrygrowers.org/ assets/docs/Hydrogen-cyanamide-use.pdf. Accessed 31 Dec 2020
Yamane H, Wada M, Honda C et al (2019) Overexpression of Prunus DAM6 inhibits growth, represses bud break competency of dormant buds and delays bud outgrowth in apple plants. PLoS ONE 14:e0214788. https://doi.org/10.1371/journal.pone.0214788

Zhang H, Tang J, Liu X-P et al (2009) Hydrogen sulfide promotes root organogenesis in Ipomoea batatas, Salix matsudana and Glycine max. J Integr Plant Biol 51:1086-1094. https://doi.org/10.1111/j. 1744-7909.2009.00885.x

Zheng C, Halaly T, Acheampong AK et al (2015) Abscisic acid (ABA) regulates grape bud dormancy, and dormancy release stimuli may act through modification of ABA metabolism. J Exp Bot 66:15271542. https://doi.org/10.1093/jxb/eru51

Zhang Z, Zhuo X, Zhao K et al (2018) Transcriptome profiles reveal the crucial roles of hormone and sugar in the bud dormancy of Prunus mume. Sci Rep 8:1-15. https://doi.org/10.1038/ s41598-018-23108-9

Publisher's Note Springer Nature remains neutral with regard to jurisdictional claims in published maps and institutional affiliations. 